\title{
NEW DIPTERA, OR TWO-WINGED FLIES, FROM AMER- ICA, ASIA, AND JAVA, WITH ADDITIONAL NOTES
}

\author{
By J. M. Aldorich
}

Associate Curator, Division of Insects, United States National Museum

This paper contains descriptions of 4 new genera, 13 new species, and 1 new variety of Diptera, together with some miscellaneous notes. It constitutes a report, which for various reasons it seems desirable to publish, on an accumulation of specimens collected from many parts of the world. All the species are represented in the United States National Museum collections by type or paratype specimens.

\section{Family CYRTIDAE}

\section{Genus OCNAEA Erichson}

Eriosoma Macquart (preoccupied), Dipteres exotiques, vol. 1, pt. 2, p. 288 (sep. p. 172), 1839.

Ocnaea Erichson, Entomographien, vol. 1, p. 155, 1840.-CoLe, Trans. Amer. Ent. Soc., vol. 45, p. 23, 1919.

Exetasis WALKER, Insecta Saundersiana, p. 203, 1852.

Two species were originally included in Ocnaea, both new, micans from Mexico and longicornis from Brazil; the second was figured. Coquillett $^{1}$ designated Ocnaea micans as the type species. Macquart designated Acrocera calida Wiedemann as type of his Eriosoma. Exetasis contained originally but one species, tumens, new, which is therefore the type; Loew ${ }^{2}$ placed the genus as a synonym of Ocnaea.

The genus has very striking characters. The proboscis is very short; the densely hairy eyes are contiguous from the mouth almost to the vertex; there is a short frontal triangle bearing the antennae; the anterior ocellus is absent; the antennae have a greatly elongated third antennal joint, curving downward, not bearing a style or arista. The venation is complete and in general not unlike that of Tabanus, except in a few variable details and in the regular occurrence of a cross vein in the first posterior cell at or beyond the

${ }^{1}$ Proc. U. S. Nat. Mus., vol. 37, p. 577, 1910.

${ }^{2}$ Wiener Ent. Monatsschr., vol. 1, p. 34, 1856.

No. 2932.-Proceedings U. S. National museum, Vol. 81, Art. 9. $110571-32-1$ 
tip of the discal. The third vein is not always forked near the tip. but this fork occurs in the genotype (mentioned in the note after the description of longicornis, which lacks it); it does not occur in the genotype of Exetasis. There is a marked tendency toward the development of adventitious cross veins, which apparently have very slight taxonomic value. Considerable variation exists in the apical part of the first posterior cell, which may be petiolate or closed in the margin, or partially coalesced with the second posterior by the disappearance of the last part of the fourth vein, or widely open. In drawing up a key largely from figures and descriptions, I had made considerable use of these differences, until I observed that my new species differed in the two wings of the single specimen and would run to what I had supposed were two groups of species. This discrepancy compelled me to view these differences with more caution.

The nearest related genus is Apelleia Bellardi. ${ }^{3}$ The only species included was vittata, new, from Mexico; it has bare eyes, and this was put forward as the main difference from Ocnaea. Osten Sacken described in Ocnaea a species (grossa) with bare eyes, indicating that the character is not of generic value; but it seems so to me, and I therefore transfer grossa to Apelleia. I recognize the fact that great caution should be exercised in proposing new genera in the family, where great plasticity seems to exist in characters which would elsewhere be of generic or even family rank. The problem is to find constant characters, and this implies the examination of considerable series in many species-a requirement which can hardly as yet be met in any collection. It may be that Exetasis will ultimately be restored to rank on the absence of the fork of the third vein; it would include tumens Walker (genotype), calida Wiedemann, and longicornis Erichson.

In preparing the following key, I have been able to examine only schwarzi, gigas, falcifer, flavipes, and trivittata (all in type material); Cole's figures and those of Wiedemann, Erichson, Walker, and Osten Sacken have been of great assistance, and I have studied the descriptions closely. Nevertheless it must be considered as a preliminary effort. Cole has given a key to the five species from North America, which he had seen, in the reference cited above. I still have misgivings as to the distinctness of my gigas and falcifer, which may be a single unusually variable species.

In response to a request from me, Dr. G. Enderlein very kindly sent me notes on the types of three species in the Berlin Museum (micans, longicornis, and lugubris), together with excellent figures of the venation in each case.

${ }^{8}$ Mem. Acad. Sci. Torino, vol. 21, p. 214, 1861 (or " Saggio di Ditt. Mess.," appendix, p. 17). 
KEY TO SPECIES OF OCNAEA

1. Third antennal joint clavate-_-

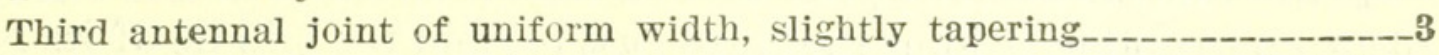

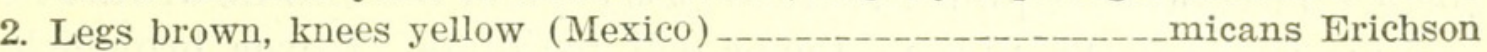
Legs yellow (Texas) -

3. Third antennal joint with scattered hairs on upper edge

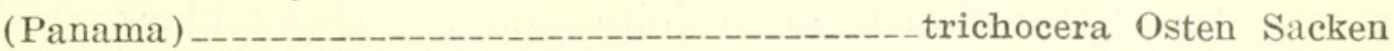

Third antennal joint bare-_-_-_-_-_- 4

4. Third vein not forked.-_-_-_.

Third vein with widely divergent anterior fork near tip, about

as in Tabanus_._- 7

5. Mesonotum luteous, legs brown (Brazil)_-_-_-_-_-_-_-_-_calida Wiedemann

Mesonotum black on disk, legs yellow

6. Scutellum yellow, third antennal joint comparatively short, less than height of eye (Brazil)-_-_-_-_-_-_-_-_-_-_-_tumens Walker

Scutellum black, third antennal joint very long, exceeding height of eye (Brazil) -

7. Femora yellow-_- 8

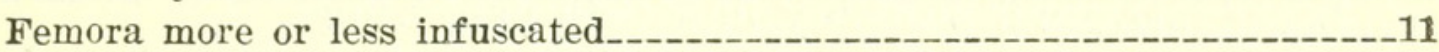

8. Mesonotum yellow (Texas) --_-_-_-_-_-_-_-_-_-_auripilosa Johnson

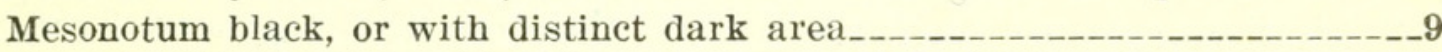

9. Second, third, and fourth abdominal segments reddish yellow with a decreasing row of black spots in middle (Honduras).

Second, third, and fourth abdominal segments with basal transverse black bands

flavipes Aldrich

10. First posterior cell petiolate by the union of the third and fourth veins before margin; adventitious cross veins present in marginal, and first and fourth posterior cells (Texas).

helluo Osten Sacken

First posterior cell united with second near tip by the disappearance of the fourth vein near base of second cell; no adventitious cross veins (the one dividing the first posterior is not here regarded as adventitious) (Cuba) schwarzi Cole

11. Mesonotum yellow with three broad black stripes confluent behind, the outer much abbreviated in front; scutellum dark yellow (Honduras) trivittata, new species

Mesonotum wholly black or blue except more or less of lateral margins; scutellum concolorous $-12$

12. Abdomen metallic blue with narrow interrupted apical yellow cross bands on second, third, and fourth segments (Texas) _-_coerulea Cole

Abdomen brown, hind edges of same segments indistinctly paler (Brazil) lugubris Gerstaecker

Abdomen without cross bands, except a broad one on second segment

13. Blackish in color, with reddish third antennal joint (Ecuador).

falcifer Aldrich

Brown in color, third antennal joint almost black (Ecuador)-gigas Aldrich 
OCNAEA TRIVITTATA, new species

Third vein forked at apex; on one side the fourth vein is incomplete, on the other it joins the third just beyond the middle of its last section, making the first posterior cell petiolate. Coxae brownish, femora irregularly brownish, not very dark; tibiae and tarsi yellow, apical half of last tarsal joint and the claws black; pulvilli yellow.

Male.-Head rather large, eyes with dense yellow pile; palpi and proboscis very minute, not visible; antennae reddish brown, first joint black above, third slender, longer than height of head, and longer than front tibia.

Thorax and abdomen with dense erect yellow pile, venter bare; mesonotum yellow with three broad black stripes confluent behind, rounded in front, the outer much abbreviated anteriorly; pleurae brown, both spiracles white; scutellum brownish yellow; calypters roughened, margin brownish yellow with pale fringe.

Abdomen shining blackish brown, first four segments with whitish hind margin of uniform width, that on first segment narrow, on the following ones conspicuous, not widening laterally except at extreme edge, where they include half the segment; they extend across venter at the width which they assume at the edge. Fifth segment with narrow pale hind border, sixth with only a lateral pale spot.

Wings small; the cross vein in the first posterior cell is more than its length beyond the discal; no indications of other unusual cross veins.

Length, $9.5 \mathrm{~mm}$.

Type--Male, U.S.N.M. No. 43480, collected by Dr. J. Bequaert at Sangrelaya, Honduras, March 13, 1924, and presented by him to the National Museum.

Remarks.-Described from one male, the type. This is the only species of Ocnaea with distinct thoracic stripes.

\section{Family DOLICHOPODIDAE}

\section{COLLINELLULA, new genus}

Very minute. Posterior half of mesonotum depressed. Antennae minute, third joint rounded, with apical bare arista; first antennal joint bare; head concave behind; proboscis and palpi small. Ocellars large, proclinate, divergent, situated high up; one outer vertical, and one frontal near eye. Face narrow in female, the eyes almost touching near epistoma; in male the eyes are contiguous below the antennae to the mouth. Thorax with two rows of rather strong acrostichals; two dorsocentrals on each side near scutellum, the row 
continuing forward as coarse setules, not much larger than the acrostichals; scutellum with a single pair of bristles, far apart. No bristle on outer side of hind coxa. Male with globose and somewhat exserted hypopygium, the abdomen rather cylindrical. Wing of male (pl. 1, fig. 2) with distorted venation; in the female (pl. 1, fig. 3) the first vein is short, the second parallel with costa nearly to tip, third vein ending just at tip, fourth diverging moderately, ending as far from tip of third as the second does, or very little farther; hind cross vein behind the center of the wing, a little shorter than last segment of fifth vein; basal cells and sixth vein absent.

Related to Achalcus, but that has five pairs of acrostichals, two before the suture. In head structure the new genus is very much like Thrypticus, but that has the venation quite different, the hind cross vein small and retracted, and the anterior part of the thorax is peculiarly bulging and prominent above. Thrypticus also has better developed dorsocentrals.

Named in honor of J. E. Collin.

Genotype.-Collinellula magistri, new species.

COLLINELLULA MAGISTRI, new species

Plate 1, Figures 2-4

Male--Very minute; dark blue-green; legs, antennae, and palpi black. Venation as figured, which alone would make the species instantly recognizable. The groups of long hairs give under low power the effect of slight clouds in the wing. Front tarsi complicated in structure; the first joint rather thick and short, widened apically; the second shorter and paler, forming an irregular collar; third somewhat like the second but excised below, the excision partly closed by a transverse plate, and the upper side of the segment with a striking spine at apex; fourth segment very short and tapering; fifth segment as long as the preceding three, very narrow at base, rapidly widening into a triangular flat shape, with dense fine hair and the usual claws and pulvilli. The tarsus is described from a specimen mounted in balsam, its small size making the details practically impossible to see otherwise. Abdomen deep green, the globose genitalia shown in posterior view and spread out (pl. 1, fig. 4), where the rest of the structures are shown in the side view, considerably pressed down. The two median ventral organs anterior to the hypopygium are especially noteworthy. Middle femora with a long bristle at base below.

Length, $1.2 \mathrm{~mm}$.

Female.-Like the male, but the wings and tarsi are normal, and the eyes do not come entirely together below the antennae, except just at the mouth.

Length, $1.1 \mathrm{~mm}$. 
Paratypes.-Male and female, U.S.N.M. No. 43658.

Remarks.-Described from 11 males and 9 females, all collected at Taughannock Falls, near Ithaca, N. Y., on August 19, 1928, by J. E. Collin, of Newmarket, England; and 1 female collected by me at Washington, D. C., on July 1, 1920. In the specific name I mean to celebrate the ability of Mr. Collin as a collector. ${ }^{3 a}$

Four males and three females of the Ithaca material are retained in the National Museum, a gift from Mr. Collin; the rest of the series, including the type, is returned to him.

A single female in the National Museum, collected by me at La Fayette, Ind., August 24, 1916, seems to belong to another species of this genus.

\section{Genus LEPTOCERA Olivier}

Leptocera Olivier, Mem. Soc. Agr. Dept. Seine, vol. 16, p. 16, 1813.-Coquillent. Proc. U. S. Nat. Mus., vol. 37, p. 559, 1910.

\section{LEPTOCERA (LIMOSINA) OPACA, new species}

Head, thorax, and abdomen black. Front opaque, two-thirds the width of head, with two pairs of convergent bristles back of vertex (one outside the other); a small divergent pair just behind ocelli; outer verticals reclinate, inner large and convergent but not decussate; ocellars proclinate and divergent; two divergent orbitals each side; three pairs convergent bordering middle region, lowest just above suture. Antennae black, decidedly divergent, separated by the triangular lunule; arista long and slender, pubescent. Face shining black, concave, epistoma protruding, narrow, prelabrum visible but not prominent; a large bristle laterally below end of suture at edge of mouth, directed forward. Cheek at narrowest hardly one-half the eye height, bare except a few hairs below. Mouth large. Mesonotum opaque, nearly circular, with 14 regular rows of hairs; suture not distinguishable. Thoracic bristles as follows: Dorsocentral, 1; prescutellar, 1 small; humeral, 1; notopleural, 1; presutural, 1; postalar, 1; mesopleural, 0 ; sternopleural, 1 ; scutellum flat, moderately long, bare, with two pairs of marginals. Halteres brownish yellow. Abdomen opaque black. Legs black. Coxae and trochanters yellow, the former more brownish; tarsi brownish, middle and hind often yellowish. Mid tibia of female with one smallish ventral bristle on middle and large apical on same side (both lacking in male), also two widely spaced bristles in both sexes on anterior dorsal surface and two beyond middle and nearly side by side on posterodorsal. Wings with slight infuscation, moderately rounded; costa without striking bristles, the segment between tips of first and second veins equal to the following; cross veins strikingly approx-

sa Dr. G. Enderlein, of Berlin, Germany, also distinguished himself as a collector by capturing both sexes of the same fly on the same occasion, as I learned from a letter received after the galley proofs of the present paper had been corrected. 
imated, their distance apart on fourth vein generally less than half the length of hind cross vein; third vein almost imperceptibly curved forward toward tip, ending only a little before tip of wing; costa extending distinctly beyond it, fourth and fifth evanescent from slightly beyond hind cross vein.

Length, 1.5-1.6 mm.

Type.-Male, U. S. N. M. No. 42847.

Remarks.-Described from 16 mounted and 14 alcoholic specimens, collected February 2, 1930, in a dahlia cellar at Fort Collins, Colorado, and sent to the Museum by Sam C. McCampbell, Deputy State Entomologist.

The species is exceedingly like heteroneura Haliday of Europe, which I have not seen. Duda's full description of heteroneura ${ }^{4}$ seems to leave few differences to note. It has the second abdominal segment in the male much elongated, but ours has it hardly any longer than the third or fourth. In the European species the face is dirty yellow; in ours it is black. These are the chief differences I see. The wing of opaca agrees with Duda's figure.

This species would go in the subgenus Scotophilella Duda. ${ }^{5}$ This subgenus, however, is a synonym of Limosina Macquart, ${ }^{6}$ as already pointed out by Richards. ${ }^{7}$

\section{Family OTITIDAE}

\section{(Ortalidae of authors)}

The generic name Ortalis being preoccupied in birds, and in fact in common use there, the family should be based upon the still older genus Otites Latreille ${ }^{8}$ (type Musca formosa Panzer). This genus belongs to the subfamily Ortalinae of authors, hence the change to Otitinae does not affect the other subfamilies.

\section{DYSCRASIS, new genus}

Belongs in subfamily Pterocallinae, but is widely different from any known genus. The presence of five pairs of well-developed dorsocentrals, and of the same number of equally large acrostichals, one pair of each being before the suture, separates the genus from all known to me. Numerous venational peculiarities, which are impressively shown in Plate 1, Figure 1, also emphasize the distinctness of this form. I was at a loss to place it in any subfamily, and referred a specimen to Professor Hendel, whose extensive publica-

\footnotetext{
Abh. K. K. Ges. Wien, vol. 10, no. 1, p. 188, 1918.

s Abh. zool.-bot. Ges., vol. 10, p. 34, 1918.

${ }^{\circ}$ Histoire naturelle des insectes, Diptères, vol. 2, p. 271, 1835.

${ }^{7}$ Proc. Zool. Soc. London, 1930, p. 291.

${ }^{\mathbf{8}}$ Histoire naturelle, générale et particulière des crustacés et des insectes, vol. 14, p. 383 , 1805 .
} 
tions in the group are well known; he places it as a peculiar form of the above subfamily.

Head broad and short (flattened from before); frons wider than one eye, with parallel sides, flat; face receding below antennae, slightly protruding at epistoma, without antennal grooves; antennae with both basal joints very short, third oval, shorter than face, with arista microscopically pubescent. Proboscis short, palpi of ordinary size, flat. Cheek a little more than half the eye height. Postvertical bristles divergent; other head bristles are inner and outer verticals; two fronto-orbitals, reclinate, the anterior halfway between inner vertical and lunule; and the usual ocellars, which are of good size. Ocellar triangle small.

Thorax narrower anteriorly than the head, almost bare of small hair, with the following bristles: Acrostichal, 1,4; dorsocentral, 1, 4; prothoracic, 0 ; humeral, 1 ; notopleural, 2 ; supraalar, 2 ; intraalar, 0 ; postalar, 2 (the outer might be taken for a low supraalar, and the inner for a high one); mesopleural, 2 small on hind edge; sternopleural, 1; scutellars, 2 pairs. Scutellum swollen, polished.

Abdomen broader than thorax, sixth joint in female (base of ovipositor) broad, flat, shining.

Legs not elongated, without noticeable bristles, except a double posterodorsal and a single longer posteroventral row on anterior femora, and a row of small ones on middle of anterior side of mid femora.

Wings (pl. 1, fig. 1) with striking pattern somewhat resembling that of the trypetid Ceratitis capitata Wiedemann. Costa without a break; costal cell very wide, the auxiliary vein sinuous, ending far before tip of first vein; first vein long, hairy above on apical half; second and third veins converging beyond small cross vein, then diverging; anal cell with a long acute extension reaching two-thirds of the way to the wing margin, and narrowed at its base.

Genotype.-Dyscrasis hendeli, new species.

\section{DYSCRASIS HENDELI, new species}

Male.-Frons gray pollinose, its lower half or less shining brown; ocellar triangle also pollinose. Face except immediately below the antennae white in ground color with very thin white pollen; cheeks and lower back of head the same but not quite so white. Thorax with two pairs of large polished black spots, above the notopleural area and wing, one before and the other behind the suture; these spots show a little velvety in some lights on their outer edge. Scutellum swollen and polished black. Remainder of dorsal region with thin gray pollen, except a small, opaque, black semicircle just before the scutellum and traces of dark spots at the bases of the 
bristles. Upper half of pleura and notopleural region with white pollen forming a sharply limited band, which passes around the metanotum below the small infrascutellum; lower half or a little less of the pleura brown. Abdomen shining black, the dorsum of the second segment, however, white pollinose, and a band of white pollen on hind edge of third and fourth segments, widest on middle of third segment. Legs brownish yellow, the femora nearly black and tarsi yellow, except near tips, where they become brownish. Wings as shown in figure and as described under the genus; the color pattern is brown, but yellow in a considerable area around the anterior cross vein.

Length, $3.5-3.7 \mathrm{~mm}$.

Female.-Like the male, but the fifth segment is white pollinose dorsally for about two-thirds of its length from the base.

Length, 4.2 to $5 \mathrm{~mm}$.

Type.-Male, U.S.N.M. No. 43575.

Remarks.-Described from 17 specimens of both sexes: Eight specimens, including type and allotype, are from Dallas, Tex., collected by F. C. Bishopp, the dates being March 29, 1907; March 17 and 20, 1908; and May 30, 1908; one male, Uvalde, Tex., in trap, November 16, 1915 (Bishopp No. 5672) ; one male and three females, Matamoras, Mexico, in traps (T. R. Stephens) ; one male, Mercedes, Tex., in trap, August 26, 1931 (W. R. Heard) ; one male, San Benito, Tex., on office window, May 26, 1930 (L. F. Greer); one female, Allen, Tex., August 14, 1931 (F. O. Swan); one female, Texas, no other data.

\section{Family RHOPACOMERIDAE}

This family has been revised by Professor Lindner in Deutsche Entomologische Zeitschrift, 1930, pp. 122-137.

\section{Genus KRÖBERIA Lindner}

Kröberia Lindner, Deutsche Ent. Zeitschr., 1930, p. 127.

The only species known is fuliginosa Lindner from southern Brazil, described in the same place. The arista is bare, the scutellum not prolonged into a blunt, shining, knoblike tip, but rounded, flat above; front flat, not concave, covered with hairs except on the ocellar triangle, which extends narrowly forward to the lunule; one or two small orbitals present; anterior edge of front somewhat overhanging the antennae in a transverse rim. Auxiliary vein well developed; fourth vein ending just before tip of wing, rather close to third. 
Dark brown, legs yellowish brown, basal and apical third of tibiae and tarsi from tip of first joint blackish. Differs from fuliginosa in having the scutellum opaque brown with pale pollinose border; the hind femora only moderately thickened, with only a few bristles above; and the hind tibiae only slightly flattened.

Male.-Front black in ground color, with thin pale pollen, ocellar triangle more densely pollinose; a silvery pollinose spot between eye and third antennal joint; face dark yellow, the protuberance sometimes blackened, the epistoma below it transversely wrinkled; cheek brown, wrinkled, nearly as high as the eye, with pale hair. Mesonotum black, with five distinct pale pollinose stripes ending at scutellum; mesopleurae with pale pollen, covered with small dark dots where the hairs arise, but these do not extend upon the portion below the spiracle. Chaetotaxy: Acrostichal, 1 (prescutellar); dorsocentral, 1 or 2 (far back); humeral, 1 ; notopleural, 2 ; presutural, 1 ; supraalar, 1 ; postalar, 2 ; intraalar, 1 (before the inner postalar); scutellar, 2 pairs (a third in one male and an odd one in a female); mesopleural, 2 or 3 ; sternopleural, 1 . Most of these bristles are quite small. Abdomen blackish, dorsum opaque, second and following segments with interrupted band of pale pollen on posterior half or more, widening toward sides to include whole length of segment, most distinct from behind. Legs as described; hind femur with anterodorsal row of bristles from base nearly to tip, and two short rows near tip, none of striking size. Wings rather uniformly pale brownish. Knob of halteres very pale yellow.

Length, 6-6.6 mm.

Female.-Abdomen with pale pollinose stripe on each side, central region opaque dark brown; sixth and seventh segments shining black, the latter becoming dark yellow toward tip.

Length, 7 to $8 \mathrm{~mm}$.

Type.-Male, U.S.N.M. No. 43761.

Remarks.-Described from two males and four females, reared from rotten wood of Sabal palmetto in Putnam County, Fla., by Mark Dodd, February 21, 1931; and one female reared by D. J. Nicholson from a larva found in decayed wood of Sabal minor, 6 inches under water, 11/2 miles east of Fort Christmas, Fla., emerged March 25, 1931.

The discovery of this species in northern Florida, only about 70 miles from the Georgia line, extends the known range of the family in a remarkable way. Lindner recognizes about 13 species in 6 genera. All these are distinctly tropical, and nearly all range southward from the northern limits of South America to Paraguay 
and northern Argentina. None have been reported from the West Indies, nor from the United States.

All the references to occurrence from Panama north are the following:

Rhinotora diversa Giglio-Tos was described from Tuxpango, Mexico.

Rhopalomera xanthops Williston was described from Yucatan; the collector being Gaumer, the species was probably taken near Merida.

Rhopalomera femorata Fabricius, described from South America, is reported by Lindner from Guatemala and Mexico.

Willistoniella pleuropunctata Wiedemann, described from South America, is reported from Playa Vicente, Mexico, by Giglio-Tos; from the Volcano Colima, Mexico, by Lindner; and I have identified it from Corozal, Canal Zone, where Mr. Zetek bred it from trunk of coconut palm.

\section{Genus SCATOPHAGA Meigen}

Scatophaga Meigen, Illiger's Mag. für Insekt., vol. 2, p. 277, 1803.

\section{SCATOPHAGA GIGANTEA, new species}

A very large species, the male with dense long fulvous hair on abdomen, legs, and pleurae; hair on mosonotum black.

Male.-Front prominent, angular at antennae; eye oblique; cheek high, especially behind, about equal to height of eye; back of head very bulging; palpi a little shorter than proboscis. Front broad, with a narrow black orbit covered with yellow pollen; frontal stripe almost half the width of the head, deep red, the middle portion blackish and having a bluish reflection; parafacial and anterior half of cheek red with bluish reflections; antennae black, third joint hardly twice the second and reaching five-sixths of the way to principal vibrissae; arista pubescent; palpi reddish yellow, with long black hairs below from near base to tip; proboscis black, its principal segment shorter than height of head. Back of head with black hair on upper half or about to lower edge of eye, the rest covered with the same long fulvous pile as the pleurae and femora. Inner vertical bristles long, ocellars slightly shorter, the row of frontals still shorter, all slender. About a dozen slender bristles in a row from epistoma to and a little above the main vibrissa.

Thorax black with dense fulvous pollen above and on the scutellum and pleurae; mesonotum with erect long delicate black hair and a few bristles; the most distinct bristles are the posterior notopleural; three supraalar; on intraalar, far back; two postalar; and 
the posterior pair of dorsocentral, far apart. Scutellum with three pairs. Sternopleural with one posterior. The long fulvous pile covers the mesopleura, propleura, and sternopleura, leaving the pteropleura and all behind it bare. Calypters with fulvous rim and marginal hairs, which are very long on the fold.

Abdomen black in ground color, with very striking long dense fulvous hair, which seems even more brightly fulvous than that of the sides of the body and the femora. This dense covering extends over the sides of the abdomen and even somewhat underneath, so that no bare area below is visible.

Legs reddish yellow, the coxae and basal three-fourths or more of femora black. Coxae with dense long fulvous pile to the outer hind side of the middle ones, this area and all the outer side of the hind ones bare; femora and tibiae with the same pile as the pleurae, but it is mainly black close to the apices of the femora, and considerably mixed with black on the extensor side of all the tibiae. Tarsi with comparatively short black hair above, about as long as the depth of the segment. Pulvilli brown, claws black. The middle tibia has two spines on the anterodorsal side, three or four on the posterodorsal, two on the posteroventral, and one on the anteroventral, not including the apicals. The hind tibiae have three spines on the anterodorsal and two on the posterodorsal. None of the femora have spines.

The wings are distinctly yellow, more intense near base.

Length, $12-15 \mathrm{~mm}$.

Female.-The characteristic red color of front, parafacials, and cheek as in male; the pile, which is so striking in the male, is reduced to insignificant size, though present. The mesonotum is deep fulvous, with the following chaetotaxy: Acrostichal, 4 delicate rows of hairs ; dorsocentral, 2, 3; humeral, 2 ; presutural, 1 ; notopleural, 2 ; supraalar, 2 ; intraalar, 1 far back; postalar, 2 ; sternopleural, 0,1 ; scutellum, with 2 pairs marginal. Abdomen depressed, with dense gray pollen, seventh segment wholly shining, except hind edge, which is notched in the middle above. Legs reddish yellow, only the front femora a little black above. No bristles on front femora; middles ones with two on front side beyond middle and two near together near tip on hind side; hind femora with irregular row of about six small on anterodorsal side. Front tibiae with two bristles on front side; middle tibiae with two anterodorsal, two posterodorsal, and one anteroventral; hind tibiae with three anterodorsal and posterodorsal.

Length, $9 \mathrm{~mm}$.

Type-Male, U.S.N.M. No. 43692, from Yu Long Gong, Tibet, August 1, 1923. Allotype from same lot. 
Remarks.-Described from 63 males and 22 females, all collected by Dr. D. C. Graham, in the high country of western China along the Tibet border and in the edge of Tibet. Ten males and one female were collected August 1, 1923, at Yu Long Gong, Tibet, near Tatsienlu, altitude 12,000 feet; 13 males and 3 females at the same place, August 12, 1930; 12 males 9 miles south of Tatsienlu, June 26 and 27,1923 , altitude 8,500 to 13,000 feet; 12 males and 1 female at $\mathrm{Yu}$ Long Si, July 26-28, 1930, altitude 14,000 to 15,900 feet; 9 males and 1 female in Yu Long Si Gorge, 13,000 to 15,000 feet, no date; and 7 males and 16 females near Wa $\mathrm{Hu}$ Pass, Tibet, August 6 and 7,1930, altitude 14,000 to 16,000 feet.

In chaetotaxy the species resembles Scatophaga vulpina Coquillett, from Point Barrow, Alaska. It is the largest species of the genus as far as I know. The lot first cited was labeled, "Fond of cowdung."

\section{SCATOPHAGA GIGANTEA OBSCURA, new variety}

A series of males differ from typical gigantea in being smaller, the pollen of the dorsum dull brown, pile of pleurae and abdomen shorter and darker, that of the femora and tibiae almost wholly black, and shorter than in the typical form. The appearance is so different that it is hard to believe the relationship so close as it appears on closer study. The head structure is the same, with the characteristic deep red color of front and face, but the pale pile of the back of the cheek is much less conspicuous. I am not able to recognize a corresponding series of females, as these males approach the typical females in their appearance, except for having in general a darker color of the thoracic pollen.

Type.-Male, U.S.N.M. No. 43693, from Yu Long Gong, Tibet. Length, 8 to $9 \mathrm{~mm}$.

Remarks.-Described from 14 males collected with typical gigantea as above cited. Ten are from Yu Long Gong, three from Wa Hu Pass, and one from Yu Long Si.

\section{SCATOPHAGA AMPLIPENNIS Portschinsky}

Scatophaga amplipennis Portschinsixy, Horae Soc. Ent. Ross., vol. 21, p. 199 1887.

Portschinsky's description is so brief that it seems worth while to give a fuller one, as a long series is available from Doctor Graham's collecting.

A slender blackish species with inconspicuous pile, but with very long and broad wings, which are uniformly dark brown in color. It agrees with Scatophaga scybalaria Linnaeus in having the attach- 
ment of the abdomen distinctly elevated above the hind coxae, so that the sclerites above the latter (metathoracic epimerit of Hendel) are completely united on the middle line, not separated by a membranous portion as in other species. It differs from scybalaria in having the arista pubescent, not pilose, in much darker color, and in other respects.

Male-Black in ground color, including femora; tibiae reddish yellow, tarsi brownish yellow; palpi yellow with brownish apices; frontal stripe very dark red with a glaucous reflection. Head dark brown above, the frontal stripe narrowed upward, the parafrontal portions wide, elevated in middle, with dense long slender bristles, of which about half a dozen of the upper series turn out over the eye, the lower ones being mesially directed. Parafacials reddish on upper half along facial ridges, elsewhere with brown pollen. Vibrissal region with dense row of bristles. Antennae wholly black, third joint less than twice the second, arista black, densely pubescent. Cheek two-thirds as high as eye, which has a somewhat diagonal position, the cheek with upturned slender hairs below, its posterior half with long and mostly yellow hairs. Palpi infuscated and with many black hairs beyond the middle, just before the middle the hairs are yellow. Thorax with dark pollen and a median glaucous stripe reaching the scutellum, on each side of this a partly double blackish, subshining stripe; scutellum glaucous on middle, connecting with the thoracic stripe. Chaetotaxy: Acrostichal, only fine, erect hairs all the way; dorsocentral, 2 hairlike anteriorly, about 3 bristles posteriorly, the hindmost gradually larger; notopleural, 2; presutural, 1 ; supraalar, 2 ; postalar, 2 ; intraalar, 0 ; sternopleural, 0,1 ; scutellum, with 2 lateral pairs and an equally long apical pair close together. Pleurae with rather dense but slender long brownish hair. Calypters brown, smallish, with fringe of dark yellow hair. Pteropleural and all behind the sternopleura bare. Halteres with brown knob.

Abdomen narrow, not much deflexed, shining brownish black, covered above and on sides with dense, erect, but rather short yellow pile, which is more or less mixed with black close to tip; this pile seems to cover the under side also.

Legs with erect but not very long pile, which varies on the femora from black to brown and a considerable admixture of yellow; front tibiae with long black pile on outer side, middle and hind ones with the same standing out all round; front tarsi with the three intermediate joints short, of equal length; pulvilli blackish, claws black; middle tibia with two anterodorsal spines beyond middle, two posterodorsal, one flexor far down toward tip; hind tibia with three anterodorsal, three posterodorsal (one near base). 
Wings strikingly long and wide, and of uniform dark brown color, only the anterior part near base gradually a little yellowish. In a male measuring $9.5 \mathrm{~mm}$, the wings measured 12.5 long and 5 wide at middle. First posterior cell not narrowed at tip, hind cross vein bisinuate.

Length, 7.5-10 $\mathrm{mm}$.

Female.-Wing not so strikingly enlarged; in a specimen $8 \mathrm{~mm}$ long the wing measured $8 \mathrm{~mm}$ long and $2.5 \mathrm{~mm}$ wide; wing color a little paler than in male; abdomen depressed as in most species and much wider across middle than in the male. Front tibia with two hairlike extensor bristles; middle tibia with two anterodorsal spines; three posterodorsal; one flexor; hind tibia with three anterodorsal; three posterodorsal.

Length, 6.4-8 $\mathrm{mm}$.

Remarks.-Redescribed from 35 males and 13 females, collected by Dr. David C. Graham in the high altitudes along the Tibet-China boundary. Four males were collected in Yellow Dragon Gorge near Song-Pan, altitude 12,000 to 14,000 feet, in the summer of 1924; all the others were collected at Yu Long Si, near Tatsienlu, July 26-28, 1930 , altitude 14,000 to 15,900 feet.

\section{Genus SARCOPHAGA Meigen}

Sarcophaga Meigen, Systematische Beschreibung, vol. 5, p. 14, 1826.

SARCOPHAGA (BLAESOXIPHA) VALANGAE, new species

Figure 1

Male.-First vein bare, posterior dorsocentrals generally three, but a small or even a normal additional one may occur as the second behind the suture; without villous hairs on inner side of hind tibia; genital segments dull black or dark brown.

Front 0.18 of head width, at narrowest, above middle (four measured $0.18,0.18,0.19,0.18)$; ocellars normal, proclinate; outer vertical not differentiated; two upper frontals reclinate but the second pair partly convergent; eight other frontals in row, which extends to near tip of second antennal joint and diverges toward eye; parafrontals narrow, brownish above, subsilvery below; frontal stripe brown; parafacials subsilvery, a changeable dark spot in the pollen at lowest frontals, the parafacial hairs rather numerous and bristly below; facial ridges broadly curved outward in middle of the face, converging markedly below, with small irregular setules extending halfway up; middle of face blackish; cheek two-fifths of eye height, with black hair except on hind edge; back of head with black hair, only a little pale about neck and below. Palpi black, proboscis ordinary. Antennae black; third joint one and one-half times the 
second; arista with rather short plumosity for less than half its length.

Thorax gray, with three black stripes and a partial one above the wing extending a little before the suture, the median stripe extending nearly to tip of scutellum; at least three pairs of large and somewhat irregular anterior and four pairs posterior acrostichals; sternopleural 3 ; scutellum with three pairs lateral, one discal, the apical pair quite large, subdepressed, decussate. Hind calypter distinctly brownish.

Abdomen gray with medium black stripe becoming slender on fourth segment, and one less distinct lateral black stripe each side, changeable on third segment and ending at middle of fourth; a pair of median marginals on second segment, marginal row on third

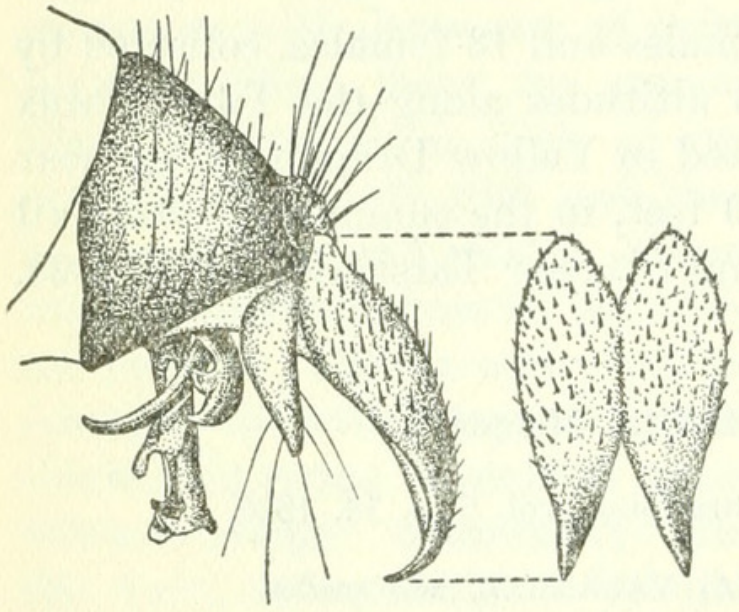

Figure 1.-Sarcophaga (Blaesoxipha) valangae, new species. Side view of male genitalia with forceps from behind. (Drawn by David G. Hall) and fourth. Genital segments brownish, small; genitalia as in Figure 1. Forceps flattened behind, brown basally; outer forceps (accessory plate of Parker) rather large for a Sarcophaga, brown basally; penis very small. In the figure the anterior and posterior claspers change places, crossing each other at base. Fifth sternite deeply cleft, without striking characters.

Legs black, front tibia with one bristle on hind side; middle tibia with one on outer front.

Wings subhyaline, costal segment before first vein equal to the one beyond second; third vein with bristles extending more than halfway to anterior cross vein.

Length, $7 \mathrm{~mm}$.

Female.-Much grayer, the black thoracic stripes narrower and the median one hardly visible on scutellum. Front near vertex 0.29 of head width (four measured $0.29,0.3,0.28,0.28$ ) ; parafacials with fewer setules; abdomen more tessellated, median stripe much less distinct, the lateral hardly noticeable. Second segment without median marginals, at most with depressed bristly hairs. Terminal ventral sclerite yellowish, a little elongated, tapering, slightly curved downward. Posterior dorsocentrals uniformly three.

Length, $6 \mathrm{~mm}$.

Type.-Male, U.S.N.M. No. 43689. 
Remarks.-Described from five males and 15 females, reared from the locust Valanga nigricornis Burmeister, at Gedangan, central Java, by F. Verbeek, December, 1929, and sent to the National Museum by Dr. S. Leefmans, of Buitenzorg, to whom a pair of paratypes are returned.

The species is very similar to those that in Europe have been regarded as belonging to the genus Blaesoxipha. The male is readily distinguishable from all European forms known to me, in having the forceps much broader toward the base and the anterior claspers with a lobe on the front near the middle.

\section{Genus LESKIOMIMA Brauer and Bergenstamm}

Leskiomima Brauer and Bergenstamm, Zweifiügler des kaiserl. Museums zu Wien, pt. 5, p. 372, 1891 (Denkschr. kaiserl. Akad. Wiss., vol. 58).

LESKIOMIMA JAYNESI, new species

A slender yellowish fiy, differing from the type species tenera in having only one to three coarse hairs at middle of first vein instead of a full series on all its length becoming more densely placed near tip. Palpi of ordinary size; proboscis (last joint) long and slender (one and one-third times the head height), curved downward, with small labella. Eyes bare. Face slightly receding, epistoma not prominent. Ocellars present, proclinate and divergent; a single pair of large verticals; two upper frontals reclinate, the uppermost, however, very small, the lowest at middle of second antennal joint; parafacial about as wide as third antennal joint. Cheek two-fifths the eye height. Front in both sexes wide, about 0.35 of head width, and with proclinate orbitals in both; pollen of head mostly white, but not silvery. Antennae red, third joint blackened on apical twothirds; second joint about half the third. Arista black, strongly pubescent. Mesonotum mostly black in ground color, with yellowish pollen, forming indistinct stripes. Acrostichal, 2, 1 (none just before suture) ; dorsocentral, 2, 3; humeral, 2 ; posthumeral, 1 ; presutural, 1 ; notopleural, 2 ; supraalar, 2 (hind small) ; intraalar, 2 ; postalar, 2; sternopleural, 2, 1; scutellum, with 1 lateral and 1 long, depressed, parallel apical. Pleurae yellow in ground color. Abdomen yellow, shining, with distinct narrow basal band of pale pollen on segments 2 to 4 ; no median marginals on first segment, a pair on second, marginal row on third and fourth; no discals even on fourth. Legs yellow, tarsi black. Wings with yellowish tinge, not at all elongated; fourth vein with rounded oblique bend ending not very far before tip. Costal segment before tip of first vein, considerably shorter than that between tips of second and third; hind cross vein straight and suberect. 
Male with small claws and pulvilli; genitalia yellow; a small blackish spot at hind edge of third and fourth abdominal segments.

Length of male, $5.5 \mathrm{~mm}$; of female, $5.6-7 \mathrm{~mm}$.

Type.-Male, U.S.N.M. No. 43062.

Remarks.-Described from 3 males and 10 females, all but one of which were reared from the sugarcane borer, Diatraea saccharalis Fabricius, at Tucuman, Argentina. Eleven were reared by H. A. Jaynes and one by H. E. Box. The other specimen was collected by H. H. Smith at "Piedras B.," Brazil, in April; it belongs to the collection of the American Museum of Natural History, to which it is returned.

\section{SCHISTOCHILUS, new genus}

Runs to Atractochaeta Brauer and Bergenstamm in Stein's 1924 "Key to the Central European Tachinidae," ${ }^{9}$ but differs in numerous characters. Eyes bare, head in profile almost triangular, the length at vibrissae being less than one-half of that at antennae. Front long, almost horizontal, in male a little more than one-third the head width; face much receding, longer than front; third antennal joint elongated, four times the second, its upper edge straight, lower rounded forward at the apex, the sharp tip in line with upper edge. Parafacial bare, as wide as third antennal joint; facial ridges bristly on lower third. Clypeus deeply depressed, forming a single groove for the reception of the antennae, which are out of sight in profile when depressed; the groove continues to the mouth through epistoma. Arista bare, shorter than the third antennal joint, very thick and blunt, the terminal joint shorter than the preceding one. Proboscis short and small, palpi rather small. Cheek two-fifths of eye height. Outer vertical small, inner large, not decussate. Ocellars of ordinary size, proclinate and diverging. Frontals in a single row, one upper reclinate, the lowest at about the middle of the second antennal joint. One proclinate orbital in male. Prosternum with a row of black setules on each side, propleura bare. Scutellum with two pairs of laterals, the apicals small, depressed, not decussate; postscutellum well developed, but joined rather closely to the scutellum so that the transverse groove below it is much deeper than the one above. Abdomen of ordinary length, wider beyond the middle than the thorax, no discal bristles. First vein of wing bare, third with a single bristle at base. First basal cell narrow, the anterior cross vein short; apical cell widening uniformly to bend, which is rectangular and slightly rounded; apical cross vein erect, joining third vein before the tip, the petiole more than onethird as long as the cross vein and ending far before wing tip. Squamae bare, rounded, not very large.

Genotype.-Schistochilus aristatum, new species. ${ }^{10}$

- Arch. für Naturg., vol. 90A, p. 19, 1924.

${ }^{10}$ The genus is of neuter gender, derived from the Greek cheilos (lip). 
Color black, mostly gray-pollinose.

Mate.-Frontal stripe brownish toward arista and the same color extending vaguely down along the edge of the lunule. Pollen of parafrontals and parafacials and posterior orbit dull gray. Palpi and basal joints of antennae dark yellow. Thorax black, with gray pollen, leaving two slender submedian stripes interrupted at the suture, an indistinct wider interrupted outer stripe. Chaetotaxy: Acrostichal, 2, 4; dorsocentral, 3, 4 (the posterior may be only 3); humeral, 2 ; notopleural, 2 ; posthumeral, 1 (inner) ; presutural, 1 ; supraalar, 2 ; intraalar, apparently 0 ; postalar, 2 ; sternopleural, 1, 1; pteropleural small. Scutellum black at base and margin. Abdomen shining black, with basal gray-pollinose bands on second to fourth segments, narrowed in middle on the first and covering about onethird of the segment except on the fourth where in certain lights the pollen extends almost to the tip; first and second segments without median marginals; third with a depressed pair; fourth with a row at apex of varying sizes. Genitalia small, of ordinary structure, the outer forceps almost as long as the inner. Wing quite distinctly infuscated, the color following the veins broadly, leaving a subhyaline spot in the middle of the apical cell and the margin irregularly of the same color. Base of wing distinctly paler. Squama white. Costal spine small but distinct. The costal segment before tip of second vein about one and one-third times as long as the one beyond it. Hind cross vein concave outward, joining fourth vein barely beyond middle between small cross vein and bend. Legs black; claws and pulvilli not at all elongated; middle tibia with a single bristle on anterodorsal side and one on ventral; hind tibia with a single sparse row of bristles of varying size on anterodorsal side.

Length, $5.8 \mathrm{~mm}$.

Type.-Male, U. S. N. M. No. 43690.

Remarks.-Described from three males, reared from Diatraea striatalis Snellen, at Pasoeroean, Java, April, 1931, by Dr. P. C. Hart, received from Dr. S. Leefmans, to whom one paratype is returned.

I am unable to find a genus more nearly related to this than Atractochaeta, from which it differs markedly in having the deep facial groove for the antennae, the face more receding, apical cross vein more erect, and first vein bare and third with only a single setule, as well as in minor characters.

\section{Genus ZENILLIA Robineau-Desvoidy}

Zenillia Robinead-Desvoidy, Essai sur les Myodaires, p. 152, 1830.-ALDRICH and Webber, Proc. U. S. Nat. Mus., vol. 63, art. 17, p. 7, 1924. 
Black with ochraceous pollen on the head, thorax, and abdomen.

Female.-Head 0.27 to 0.31 of the head width; the frontal stripe velvet brown, as wide as one parafrontal; parafrontal, parafacial, and posterior orbit with almost golden yellow pollen, that of the face and cheek gray, with a slight tinge of yellow; front somewhat prominent at the insertion of the antennae, forming a slightly oblique angle with the face, the frontal profile and the facial of about the same length. Parafacial at middle as wide as third antennal joint, facial ridges with only three or four hairs above the vibrissae, which are far apart at the oral margin. Cheek one-fifth the eye height. Antennae black, tip of second joint reddish, third joint long and slender, fully four times the second, rounded at tip, reaching almost to vibrissae. Arista rather long and slender, slightly thickened on

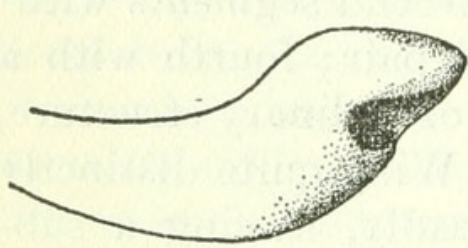

Figure 2.-Zenillia palpalis, new species. Palpus of female, outer side. (Drawn by C. T. Greene) basal third. Palpi (fig. 2) considerably swollen, with a very distinct and striking pocketlike depression or hole on the outer side just before the tip, which is the same in all the specimens. Inner verticals large, outer much smaller; ocellars of good size; two upper frontals reclinate, the remaining in a single row diverging below toward orbit, reaching to the base of third joint; the usual two proclinate orbitals; parafrontal with only inconspicuous hairs besides the bristles. Mesonotum covered with yellowish pollen, which forms principally three stripes on the sides and middle, leaving a rather heavy black stripe on each side, which is divided anteriorly, the inner and narrower portion extending to the neck. Scutellum with yellow pollen. Thoracic bristles rather stout. Chatotaxy as follows: Acrostichal, 4, 3; dorsocentral, 3, 4; humeral, 4; notopleural, 2 ; posthumeral, 3 ; presutural, 2 (the inner large); supraalar, 3 ; intraalar, 3 ; postalar, 3 (the middle one large, the others small); sternopleural, 2, 1; pteropleural small. Scutellum with 3 pairs lateral, 1 discal, the apicals slender and upturned, rather long. Propleura bare, prosternum setose, postalar declivity bare, no infrasquamal setules. Scutellum densely covered with coarse erect rather short hairs. Abdomen largely shining black, the yellow pollen forming basal bands on the second and third segments, which are wide at the side and prolonged posteriorly in a blunt point in the middle, leaving considerably more than half the surface shining; fourth segment with yellow pollen except an oval median spot above, which covers the apical two-thirds, but does not extend on the sides. 
First and second abdominal segments each bearing one pair of median marginals; second and third with one pair of smallish discals, which are quite far forward on the yellow pollinose portion; third with a marginal row, the middle pair very large and stout; fourth segment with irregular bristles extending forward nearly to the base, no distinct row on posterior margin. The terminal ventral segment when exposed appears as a cylindrical tubular structure, not very long, bearing at its apex a minute, shining black prolongation, grooved above, bearing microscopic hairs. Legs black, middle tibia with one bristle on the outer front side and one flexor; hind tibia with an inconspicuous row of small bristles and two larger ones rather far apart almost dividing the length into thirds. Wings a little brownish; third vein with two to four bristles at base; fourth vein with a round oblique curve, the apical cross vein more slender, straight for two-thirds of its length and almost parallel with the margin, then gradually curved toward the tip, joining the costa quite close to the tip a little distance from the third; hind cross vein suberect, joining fourth at two-thirds of the distance from the small cross vein to the bend. Hind calypter light brownish with pale margin; the front one white and subtransparent.

Length, 8-9 mm.

Male.-Front at level of anterior ocellus 0.27 of head width; no orbitals, third antennal joint a little broader than in female, of the same length; palpi distinctly flattened and a little widened at tip, but lacking the pore which is so striking in the female; eyes with same pilosity as in female. Genitalia small, black, the inner forceps straight, slender and close together, the outer slender and almost as long; penis black, slender, with a delicate white flap on front at tip. Claws and pulvilli moderately long.

Paratypes.-Female, U.S.N.M. No. 43691.

Remarks.-Described from five females and one male, reared at Wanaina, Northwest District, British Guiana, March, 1931, by J. G. Myers, from Castnia licoides Boisduval. The specimens were received from the Imperial Institute of Entomology, to which the type female, allotype male, and two paratype females are returned.

The peculiar depression, or perhaps a sensory pit, in the palpus does not occur in any other tachinid known to me. It occurs only in the female. The species is distinguished by rather stout bristles throughout. I have compared the type series carefully with Zenillia libatrix Panzer (det. Bezzi) and find it agrees well except in having a single bristle on the anteroventral side of the middle tibia. No fine hairlike bristles extending up facial ridges, and in the visible structures at the tip of the abdomen in the female; in libatrix the terminal organs are concealed in our specimens by closure of the fourth abdominal segment in a longitudinal slit. 
TROPHOPS, new genus

Somewhat allied to Pexomyia (mbrifrons Perris, the genotype), but differing in having the vibrissae distinctly above oral margin, no costal spine nor infrasquamal setules.

Hypopleural bristles and postscutellum present; eyes and arista bare; palpi and proboscis of ordinary form; parafrontals and parafacials broad, especially the latter, which are bare and about half as wide as clypeal depression; facial ridges bare, low, vibrissae far apart and much above the epistoma, only a little below the lowest curve of the eye; cheeks broad and bulging, almost half the eye height. Third antennal joint nearly three times the second, rather slender and tapering, not quite reaching vibrissae. Length of head at antennae slightly greater than at vibrissae; frontal profile a little greater than facial; clypeus flat, moderately broad.

Scutellum with three lateral pairs of bristles, the apical pair almost equally large, decussate or not, depressed. No discal abdominal bristles on second and third segments.

First vein bare, third with one or two bristles at base, fourth with bend slightly rounded, thence a little concave, ending distinctly, yet not very far before apex of wing. Hind cross vein concave and a little oblique, joining fourth vein at three-fifths of the distance from anterior cross vein to bend.

Genotype.-Trophops clauseni, new species.

TROPHOPS CLAUSENI, new species

Black with yellowish pollen on head and thorax. Abdomen shining black with broad bands of gray pollen on the second, third, and fourth segments.

Male.-Front 0.31 of the head width. Head with somewhat silvery pollen except on front and upper orbits where it is distinctly yellow. Frontal stripe wider than one parafacial. Verticals one pair; ocellars of normal size and proclinate; two upper orbitals reclinate, strong, the others rather weak, the lowest at middle of second antennal joint. Antennae black, tip of second joint and basal third of third joint reddish; third joint decidedly slender and tapering, a little more than twice the second, not reaching to vibrissae. Cheek covered with fine dark hair. Palpi brown. Thorax with a pair of very slender stripes outside the acrostichals, much enlarged behind the suture; an outer stripe is broadly divided into two spots, the hindmost elongated. Pleurae black with thin gray pollen. Chaetotaxy : Acrostichal, 3, 3; dorsocentral, 3, 4; humeral, 2; posthumeral, 2 ; notopleural, 2 ; presutural, 2 (the inner rather large); supraalar, 3 ; intraalar, 3 ; postalar, 2 ; sternopleural, 2,1 ; pteropleural small. No 
infrasquamal setules. Propleura and prosternum bare. Abdomen mostly shining black, basal two-thirds of second segment, one-half of third segment, and two-thirds of fourth segment with gray pollen. A delicate median black line on these segments. No marginals on first segment, those of second depressed and inconspicuous, third with a median pair and two lateral, fourth with a marginal row and a single subdiscal pair far back. Genitalia black. Legs black (only hind ones present) ; hind tibiae with rather dense fringe of uniform bristles on anterodorsal side. Hind pulvilli and claws elongated. Wing considerably brownish except along the veins. Costal segment beyond the first vein only slightly longer than the one before it. Calypters white; margin narrow, brownish yellow.

Length, $7.4 \mathrm{~mm}$.

Female.-Front 0.37 of head width (the same in two); usual two pairs of orbital bristles, below the lowest frontals a distinct pollinose dark band extends from the eye to the suture (faintly indicated in male). Hindmost sclerite of venter broadly rounded. Middle tibia with two bristles on anterodorsal side. Claws and pulvilli small.

\section{Length, 5.7-7.7 mm.}

\section{Type.-Male, U. S. N. M. No. 43695.}

Remarks.-Described from one male and three females (one of the latter considerably broken), reared from Popillia japonica Newman; male and two females at Toyona, Japan, July 9, 1930, by T. R. Gardner; the other female, which is broken, at Takarozawa, Japan, by C. P. Clausen, July, 1928. The species is named in honor of C. P. Clausen, who has made an extensive study of the Japanese beetle parasites in Japan and adjacent regions.

\section{Genus EXORISTOIDES Coquillett}

Exoristoides Coquillett, Revision of the Tachinidae of America north of Mexico, p. 90, 1897.-Walton, Proc. Ent. Soc. Washington, vol. 17, p. 96, 1915.Aldrich and WebBer. Proc. U. S. Nat. Mus., vol. 63, art. 17, p. 10, 1924.Curran, Can. Ent., vol. 58, p. 85, 1926.

Exoristopsis Townsend, Proc. U. S. Nat. Mus., vol. 49, p. 426, 1915.

The genotype of Exoristoides, designated by Coquillett in 1897, is johnsoni Coquillett; that of Exoristopsis, designaied by Townsend in 1915, is setifera Townsend.

The genus has the general characters of Exorista of authors (Zenillia sens. lat. of Aldrich and Webber, 1924), with the addition of a large pteropleural bristle and almost invariably some setules on the first vein. Curran suggests that Lypha is a near relative, which is true. Townsend placed one of our species (slossonae) in Lydina (Polidea of authors), in the National Museum collection some years ago, and this also expressed a true relation. Lypha may be distin- 
guished by the frontal bristles, which extend remarkably far down on the parafacials; and both genera differ from Exoristoides in having the eyes smaller and cheek wider, as well as in lacking any hairs on the first vein. In the single known specimen of Exoristopsis both pteropleurals are broken off, but the large scars are present.

Three species were originally included, johnsoni, slossonae, and harringtoni, of which the last has been removed as type species of the genus Homalactia Townsend.

KEY TO SPECIES OF EXORISTOIDES

MALES

1. Third antennal joint very wide, two-thirds as wide as long, with obliquely truncate apex (North Carolina to Louisiana and California ) johnsoni Coquillett

Third antennal joint less than half as wide as long 2

2. First vein with few setules, rarely none; fourth abdominal segment wholly black (New Hampshire to Alabama) _...-_slossonae Coquillett

First vein with complete series of setules from near humeral cross vein (Trinidad, West Indies) urichi, new species

FEMALES

1. First vein setulose from near humeral cross vein to tip $-2$

First vein with only a few setules, at most on basal half $-3$

2. Third antennal joint concave on front edge, widened at tip.

urichi, new species

Third antennal joint straight, not widened apically (Peru).

setifera Townsend

3. Sternopleurals two; fourth abdominal segment red johnsoni Coquillett Sternopleurals three; fourth abdominal segment wholly black.

slossonae Coquillett

\section{EXORISTOIDES JOHNSONI Coquillett}

Exoristoides johnsoni CoquILLET, Revision of the Tachinidae of America north of Mexico, p. 91, 1897.-Walton, Proc. Ent. Soc. Washington, vol. 17, p. 97, 1915.-Brimlex, Ent. News, vol. 33, p. 22, 1922.

The material in the National Museum at present referred to this species is the following: Holotype, female, Hertford County, N. C. (collection Coquillett); one female, Raleigh, N. C. (Brimley); one female, Palo Alto, Calif. (W.F. Derby coll., through the Aldrich collection) ; one female, Opelousas, La. (Pilate) ; one female, Lindsey, Calif. (McGregor); one dwarf male, reared at Capa, S. Dak., from Gryllus abbreviatus Serville, by Prof. H. C. Severin, emerged September 12, 1919; two males and one female, reared at Sacramento, Calif., from Gryllus assimitis Fabricius, by C. C. Wilson, emerged March 27, 1930; and one female, reared at Winters, Calif., by the same entomologist from the same host, emerged April 10, 1931. Thus there are three different rearing records from Gryllus, and these are the only ones yet known. 


\section{EXORISTOIDES SLOSSONAE Coquillett}

Exoristoides slossonae Coquillett, Revision of the Tachinidae of America north of Mexico, p. 91, 1897.-Johnson, Catalogue of the insects of New Jersey, p. 671,1899 , and p. $779,1910 .-B a n k s$, Ent. News, vol. 23, p. 110, 1912.Walton, Proc. Ent. Soc. Washington, vol. 17, p. 97, 1915.-Britton, Checklist of the insects of Connecticut, p. 192, 1920.-Brimler, Ent. News, vol. 33, p. 22, 1922.-JoHnson, List of the Diptera of New England, p. 199, 1925.-West, A list of the insects of New York (Cornell Univ. Agr. Exp. Sta. Mem. 101), p. 815, 1928.-Allen, Ann. Ent. Soc. America, vol. 22, p. 687, 1929.-Curran, Bull. Amer. Mus. Nat. Hist., vol. 61, p. 106, 1930.

Exorista spinipennis Coqullletr, Revision of the Tachinidae of America north of Mexico, p. 95, 1897.-Johnson, Ent. News, vol. 15, p. 157, 1904; Catalogue of insects of New Jersey, p. 780, 1910.-Sмrth, Psyche, vol. 24, p. 58, 1917 (syn.).-Gibson, Ann. Rep. Ent. Soc. Ontario, p. 119, 1918.Aldrich and Webber, Proc. U. S. Nat. Mus. vol. 63, art. 17, p. 10, 1924.

The material in the National Museum referred to slossonae is as follows: Four types of slossonae, both sexes, from Franconia, N. H. (Mrs. Slosson), Eastport, Me. (coll. C. V. Riley), and Westville, N. J. (Johnson); the female type of spinipennis Coquillett, from Tifton, Ga. (Pilate); a female from Franconia, N. H. (Townsend); a male from Chevy Chase Lake, Md. (Townsend); a female from Potomac Run, Va. (McAtee); two males from College Park, Md. (Walton); a male from La Fayette, Ind. (Aldrich); and a male from Birmingham, Ala., reared by H. L. Weatherbee from Epilachna corrupta Mulsant, the Mexican bean beetle. The last emerged on August 3, 1922, and this is the only rearing record.

\section{EXORISTOIDES SETIFERA Townsend}

Exoristopsis setifera Townsend, Proc. U. S. Nat. Mus., vol. 49, p. 426, 1915.

The only specimen in the National Museum is the type, a female from Peru.

The characters given for the genus Exoristopsis by Townsend seem mostly specific, especially when considered in relation to the other species than johnsoni, which I here include. Perhaps the most important is the small size of the ocellars, which is shared by urichi, new species. No mention is made of the pteropleurals, which are broken off, but the scars are distinct.

\section{EXORISTOIDES URICHI, new species}

Black with silvery-gray pollen. Fourth abdominal segment red or reddish in ground color with yellow pollen.

Male.-Front 0.27 of head width, pollen of the head silvery gray, the posterior orbit and upper part of front slightly yellow. Ocellars hairlike, proclinate, two upper frontals reclinate, six others, the lowest at the level of the base of third antennal joint. Antennae 
mostly black; tip of second and base of third antennal joints reddish. this color extending to the middle of the third on inner side; third antennal joint three times the second, rather wide, at its middle almost twice as wide as the parafacial, somewhat prominent at base and tip on the front side, leaving a distinct concavity between, the apex truncate, reaching nearly to vibrissae. Arista with penultimate joint a little elongate, barely twice as long as thick, the apical joint rather short, thickened nearly to the middle. Eyes with long pile. Cheek a little more than one-fourth the eye height. Palpi slender, yellow apically, dark brown on basal half; outer verticals distinct, three-fourths as long as the inner. Mesonotum with rather thin silvery-gray pollen, leaving four longitudinal shining black stripes, the inner narrow and reaching halfway from the suture to the scutellum; an elongate median spot before the scutellum. Acrostichal 3, 3; dorsocentral, 3, 3; sternopleural, 2, 1 . Scutellum, with 3 lateral bristles, a small erect nondecussate hairlike apical pair. Propleura and prosternum bare. Second and third segments of abdomen of same color as thorax, in some lights showing pollen to the apices of the segments; fourth segment with more yellowish pollen, the ground color rather dark red; first segment with no median marginals, second with one pair, third with a median pair and two or three at the margin; second and third segments with a single pair of discals much smaller than marginals; fourth segment with a median row of six large bristles and a marginal row of the same number considerably smaller. Genitalia red, small, very similar to those of the other species; the inner forceps blackish, being united into a beaklike process curved upward and acute at tip; outer forceps slender, curved like the inner with a minute tooth at apex. Legs black, all the tarsi rather short and decreasing in width. All the claws and pulvilli very small. Front tibiae with two bristles near middle on posteroventral side; middle tibiae with four bristles on anterodorsal side, the two middle ones quite long, and with one ventral; hind tibiae with an uneven sparse row on anterodorsal side. Wings hyaline, the first vein hairy to tip from humeral cross vein; third vein with coarse hairs nearly to cross vein; fourth vein with rounded almost rectangular bend, then concave, reaching costa only a little before apex. The first posterior cell open. Hind cross vein straight, somewhat oblique, joining fourth vein considerably beyond middle of the distance between anterior cross vein and bend. Calypters white, the hind ones subtransparent; infrasquamal setules present but delicate.

Length, $6.5 \mathrm{~mm}$.

Female.-Front at vertex 0.27 of the head width. The pollen on upper two-thirds much more distinctly yellow than in the male. Third antennal joint more than twice the second, distinctly wider 
than the parafacial, its tip widened about as in the male but the basal part not protruding noticeably in the vicinity of the arista. Palpi as in the male. Fourth abdominal segment distinctly red in ground color, shining in some lights over most of its surface. Genitalia simple. Front tarsi a little widened from the second joint, the claws and pulvilli very small.

Length, $6.2 \mathrm{~mm}$.

Type.-In the British Museum of Natural History.

Remarks.-Described from one male and one female, reared in Trinidad, West Indies, by F. W. Urich, from pupae of Calpodes ethlius Cramer. The specimens were received from Sir Guy A. K. Marshall, director of the Imperial Institute of Entomology, in London, to whom they are returned for ultimate deposit in the British Museum.

\section{Genus ACHAETONEURA Brauer and Bergenstamm}

Achaetoneura Brauer and Bergenstama, Zweiflügler des kaiserl. Museums zu Wien, pt. 5, p. 334, 1891 (Denkschr. kaiserl. Akad. Wiss., vol. 58).-WEBBER, Proc. U. S. Nat. Mus., vol. 78, art. 10, p. 1, 1930.

ACHAETONEURA NIGRIPALPIS, new species

Entirely black, including antennae, palpi, and scutellum.

Female.-Front at vertex $0.3,0.31$ (in the two specimens) of the head height. Head with silvery pollen tinged with light yellow on the front; third antennal joint two and one-half times the second. Arista slender, bare, third joint very slightly thickened basally. Parafacial a little wider than third antennal joint. Facial ridges with rather small bristles extending to middle of third antennal joint. Cheek one-fourth eye height. Thorax gray pollinose with four black stripes, the inner pair abbreviated behind and the outer interrupted at suture. Scutellum subshining black at base. Acrostichal, 3, 3; dorsocentral, 3, 4; scutellum, with 3 lateral pairs of bristles, the apicals rather strong, decussate, depressed; sternopleural, 2, 2, the anterior of the hindmost somewhat hairlike; propleura bare. First abdominal segment black, the second and third black on apical two-fifths, their bases with smooth gray pollen which is sharply defined behind; fourth segment wholly pollinose with a slight yellow tinge. No discals on second and third segments, a pair of marginals on first and second, marginal row of six on the third; fourth with a row of bristles in the middle, the marginals small and inconspicuous. Venter with a somewhat reddish tinge. Legs black; anterior tibiae with two posteroventral bristles; middle tibiae with two large anterodorsal, two small posterodorsal and one ventral; hind tibiae with a complete row of small bristles on posterodorsal side, one in middle slightly larger. Anterior tarsi with third and 
fourth joints slightly flattened; claws and pulvilli small. Wings subhyaline with the usual venation for the genus; third vein with three setules at base. Calypters white.

Length, 7.6-8.5 mm.

Paratype.-Female, U. S. N. M. No. 43694.

Remarks.-Described from two females reared by F. W. Urich, in Trinidad, from pupae of Calpodes ethlius Cramer. The specimens were received from Sir Guy A. K. Marshall, of the Imperial Institute of Entomology, and the type is returned to him for ultimate deposit in the British Museum.

Compared with the females of the genotype A. frenchii Williston, the head appears a little rounder, the eye longer vertically, the third antennal joint shorter and the bristles of the facial ridges do not extend so high. In chaetotaxy and other generic characters it agrees very well. 


\section{$2 \mathrm{BHL}$ Biodiversity Heritage Library}

Aldrich, John Merton. 1932. "New Diptera, or two-winged flies from America, Asia, and Java with additional notes." Proceedings of the United States National Museum 81, 1-28. https://doi.org/10.5479/si.00963801.81-2932.1.

View This Item Online: https://www.biodiversitylibrary.org/item/32577

DOI: https://doi.org/10.5479/si.00963801.81-2932.1

Permalink: https://www.biodiversitylibrary.org/partpdf/10057.

\section{Holding Institution}

Smithsonian Libraries

\section{Sponsored by}

Smithsonian

\section{Copyright \& Reuse}

Copyright Status: NOT_IN_COPYRIGHT

Rights: https://www.biodiversitylibrary.org/permissions/

This document was created from content at the Biodiversity Heritage Library, the world's largest open access digital library for biodiversity literature and archives. Visit BHL at https://www.biodiversitylibrary.org. 